This PDF is a selection from a published volume from the National Bureau of Economic Research

Volume Title: International Trade in East Asia, NBER-East Asia Seminar on Economics, Volume 14

Volume Author/Editor: Takatoshi Ito and Andrew K. Rose, editors

Volume Publisher: University of Chicago Press

Volume ISBN: 0-226-37896-9

Volume URL: http://www.nber.org/books/ito_05-1

Conference Date: September 5-7, 2003

Publication Date: August 2005

Title: The Impacts of an East Asia Free Trade Agreement on Foreign Trade in East Asia

Author: Shujiro Urata, Kozo Kiyota

URL: http://www.nber.org/chapters/c0195 


\title{
The Impacts of an East Asia \\ Free Trade Agreement on \\ Foreign Trade in East Asia
}

\author{
Shujiro Urata and Kozo Kiyota
}

\subsection{Introduction}

The world economy has been witnessing the surge in free trade area (FTA) since the early 1990s. ${ }^{1}$ By December 2002, some 250 FTAs have been reported to the General Agreement on Tariffs and Trade/World Trade Organization (GATT/WTO), and of those 130 were reported after the establishment of the WTO in January $1995 .{ }^{2}$ More than 170 FTAs are currently in force, and 70 additional FTAs are expected to be operational, although they are not yet reported. According to the WTO, by the end of 2005, if FTAs reportedly planned or already under negotiation are concluded, the total number of FTAs in force may approach 300. Among the regions of the world, East Asia was not active in establishing FTAs until recently. Indeed, until 2002, when the Japan-Singapore FTA was enacted, the Association of Southeast Asian Nations (ASEAN) Free Trade Area (AFTA) was the only major FTA in the region. Many East Asian econ-

Shujiro Urata is a professor of economics at Waseda University, and a research fellow at the Japan Center for Economic Research. Kozo Kiyota is an associate professor in the International Graduate School of Social Sciences at Yokohama National University.

The authors would like to thank Dukgeun Ahn, Philippa Dee, Kyoji Fukao, Takatoshi Ito, Erlinda Medalla, Andrew Rose, Robert M. Stern, and the seminar participants at the Fourteenth Annual East Asia Seminar on Economics for their helpful comments and suggestions on the earlier version of the paper. Any remaining errors are the authors' alone. Kozo Kiyota was a visiting scholar at the University of Michigan, Ann Arbor, when the present version of the paper was prepared and would like to thank the Kikawada Fellowship Program for providing financial support for this research.

1. FTA means Free Trade Agreements, Free Trade Area, or Free Trade Association.

2. Under the GATT/WTO, the term regional trade agreements (RTAs), which include FTAs and customs unions, are used to describe regionalization. But in this paper we use the term FTAs to mean RTAs, as many RTAs, especially those in East Asia, are FTAs. See the WTO website at http://www.wto.org for the information on RTAs. 
omies started showing a strong interest in FTAs toward the end of the 1990s. Although East Asia has so far seen the creation of only a few FTAs, including AFTA and the Japan-Singapore FTA, it is likely to observe the establishment of many FTAs in the near future. Indeed, it may not be unrealistic to imagine the formation of the East Asia FTA, covering all East Asian countries and economies.

In light of strong interest in FTAs by East Asian economies, this paper attempts to examine the impact of the East Asia FTA on trade patterns in East Asia by using a multisector computable general equilibrium (CGE) model. Because FTA removes tariff and nontariff barriers on trade among members, the East Asia FTA is expected to have substantial impacts on the trade patterns of East Asian economies. An analysis of the impacts of an East Asia FTA is useful not only for researchers interested in trade issues but also for policymakers interested in responsible trade policies.

The structure of the paper is as follows. Section 7.2 reviews recent developments in FTAs in East Asia. Section 7.3 presents the model and the data used in the simulation analysis. One important objective of this section is to examine trade and protection patterns in East Asia to set the stage for the simulation analysis of the impact of an East Asia FTA on trade in East Asia. Section 7.4 discusses the results of the simulation. Section 7.5 concludes the paper.

\subsection{Emergence of FTAs in East Asia}

East Asia was not active in the formation of regional trade agreements, such as FTAs, until recently. ${ }^{3}$ Indeed, the AFTA was the only major FTA until Japan and Singapore enacted the Japan-Singapore FTA (formally Japan-Singapore Economic Partnership Agreement) in November 2002. This section provides a brief discussion on the recent developments concerning FTAs in East Asia.

The ASEAN Free Trade Area was established in 1992 with six ASEAN member countries: Indonesia, Malaysia, the Philippines, Singapore, Thailand, and Brunei. New ASEAN members-Vietnam, Myanmar, Cambodia, and Laos - joined AFTA in the latter half of the 1990s, and AFTA currently has ten member countries. The main objective of AFTA is to develop competitive industries in ASEAN by promoting intra-ASEAN trade. Several factors contributed to the formation of AFTA. One is the realization of the need to capture export markets in the face of increasing FTAs in the world. Another factor is the emergence of China as a competitor for attracting foreign direct investment (FDI). The end of the cold war also had an impact on ASEAN, as it made ASEAN concentrate on economic development. Besides AFTA, ASEAN as a group as well as its members have 
become active in FTA discussions with other countries. One of the FTAs involving ASEAN that has received the most attention recently is that with China, which will be discussed in the following. The ASEAN is also discussing the possibility of FTAs with Japan and Korea.

Compared to ASEAN countries in Southeast Asia, the countries in Northeast Asia including China, Japan, and Korea had not been active in FTAs until recently. Despite increasingly strong interest in FTAs by Northeast Asian countries, there is only one FTA (Japan-Singapore FTA) that has been enacted so far. Japan is currently negotiating an FTA with Mexico, and it has been studying possible FTAs with Korea, ASEAN, Thailand, Malaysia, and the Philippines. The importance of FTAs with East Asian countries for Japan and East Asia is understood by many Japanese, including policymakers and business people. However, the moves toward the formation of FTAs have been rather weak because of strong opposition from various groups such as noncompetitive farmers, who would suffer from trade liberalization of agricultural products.

Korea started having an interest in FTAs before Japan. In 1998, Korea disclosed a plan to start FTA negotiations with Chile, and it also set up a joint-study group at the private level on an FTA with Japan. Korea started negotiations with Chile in 1999, and Korea and Chile signed the agreement in October 2002 after difficult negotiations on liberalization of agricultural imports. Although the agreement was signed, it has not yet been ratified by the Korean National Assembly because of strong opposition from the farmers. Korea also started studying the possible FTA with ASEAN.

China's active FTA strategy has received a lot of attention. China joined the WTO in 2001 and established an access to the world market, and it started to pursue regional strategies by using FTAs. China signed a framework agreement on comprehensive economic cooperation with ASEAN in November 2002. The agreement, which was proposed strongly by China, includes not only trade liberalization but also cooperation in the areas of FDI and economic development. China and ASEAN started negotiations on FTA in January 2003 with a target for its conclusion by June 2004. China has offered various schemes attractive to ASEAN and particularly to its new members, such as economic cooperation for the new ASEAN members and advanced trade liberalization (early harvest) in agricultural products. In addition to ASEAN, China has proposed to Japan and Korea to establish a trilateral FTA including these three countries.

The idea of an FTA covering East Asian countries has emerged. At the Leaders' Summit meeting of ASEAN+3 (China, Japan, and Korea) in 1998, the leaders decided to set up the East Asia Vision Group to study longterm vision for economic cooperation. The group has presented the leaders with recommendations including the establishment of an East Asia FTA. Despite the recommendation from the East Asia Vision Group, the East Asia FTA has not yet become a concrete agenda at the Leaders' meeting. 
One can think of various factors that have led to an emerging interest in FTAs among the countries in East Asia. Many countries consider FTAs as an effective way to penetrate the markets of the member countries. Some countries think FTAs would promote deregulation and structural reform to revitalize their economies. The financial crisis in East Asia increased the awareness of the need for regional cooperation such as FTAs to avoid another crisis and to promote regional economic growth. Rivalry in the region has been a factor contributing to an increased interest in FTAs. Specifically, both China and Japan, which are competing to become a "leader" in the region, are keen on using FTAs to strengthen the relationships with ASEAN and the Newly Industrializing Economies (NIEs). Indeed, in November 2002, Japan proposed an economic partnership framework to ASEAN one day after China agreed to start FTA negotiations with ASEAN. It should also be noted that ASEAN and the NIEs also consider FTAs as a means to maintain and increase their influential position in East Asia.

Currently, the establishment of a China-Japan-Korea FTA appears difficult not only because of the opposition groups against trade liberalization but also because of the differences in their views on past history and other noneconomic issues. Rather than a China-Japan-Korea FTA, the establishment of three ASEAN+1 FTAs, namely ASEAN-China, ASEANJapan, and ASEAN-Korea, may be more likely. Indeed, ASEAN may be interested in establishing three ASEAN+1 FTAs to keep their negotiating position before moving to the establishment of an East Asia FTA.

Considering that an FTA would contribute to economic growth of the countries involved and considering that FTAs are likely to increase in other parts of the world, it is hoped that East Asia would work hard to establish an East Asia FTA by overcoming the obstacles with active cooperation. With these observations in mind, we attempt to investigate the likely impacts of the East Asia FTA on East Asian economies in the following sections.

\subsection{The Impacts of an East Asia FTA on East Asian Economies: A Simulation Analysis}

\subsubsection{The Model}

This section investigates the economic impacts of an East Asia FTA on East Asian economies using the standard Global Trade Analysis Project model (GTAP model) developed by Hertel (1997). ${ }^{4}$ This is a multisector,

4. The impacts of an East Asia FTA using a CGE model are also examined in Ballard and Cheong (1997) although they do not focus on the impacts on trade patterns. For more detail, see Ballard and Cheong (1997). 
multicountry computable general equilibrium (CGE) model that has been widely used in a number of studies. The characteristics of the GTAP model are summarized as follows. The demand side of the standard GTAP model assumes that total national income is allocated using fixed value shares among three kinds of final demand - government, private household, and savings - which are derived from an aggregate utility function of the CobbDouglas form. The single representative household in each country maximizes a constant difference of elasticity expenditure (CDE) function. The $\mathrm{CDE}$ function is calibrated to different income and the price elasticity of demand, and calibrated elasticity is used to specify private household demand function.

On the production side, the standard GTAP model employs constant returns-to-scale technology and perfect competition. Production in each sector in each country is represented by a multilevel production function of a Leontief form that involves value added and intermediate inputs generated from the input-output tables. The demands for factors and intermediate inputs are represented by a nested constant elasticity of substitution (CES) function. Each firm uses a CES composite of domestically produced and imported intermediate goods and determines the optimal mix of imported and domestic goods given domestic and import prices. Imports are distinguished by country of origin (Armington assumption). ${ }^{5}$

Labor is mobile across industries but not across countries. Capital is mobile across industries and countries, and its accumulation is endogenously determined. Investments are assembled to be allocated across regions through a hypothetical global sector called the global bank in such a way that the global bank equates the change in the expected rates of return across countries. Transport margins are derived from equating supply and demand in another hypothetical global sector called the global transportation sector. Equilibrium satisfies the conditions in that demand equals supply for all goods and factors, and representative firms in each industry earn zero profit.

While a standard GTAP model is useful in analyzing the impact of trade policy, there are some limitations. First, the Armington assumption may be a problem because it assumes that every country has some market power and may therefore be able to influence its terms of trade. This assumption is not realistic for small countries such as those in East Asia. Second, the model assumes perfect competition, which may not be appropriate as some sectors may have an imperfectly competitive structure. ${ }^{6}$ Third, the standard GTAP model assumes a static framework, which might cause some

5. For more details about the current standard GTAP model, see http://www.gtap.agecon .purdue.edu/products/models/current.asp.

6. There are some CGE models that include imperfect competition and scale economies. For instance, Brown, Kiyota, and Stern (2004) introduce monopolistic competition, which makes it possible to introduce intraindustry trade without the Armington assumption. 
problems in analyzing the timing of establishment of an FTA. ${ }^{7}$ Fourth, the standard GTAP model does not incorporate FDI partly because of the limited availability of bilateral FDI flow data at the sectoral level and difficulty in modeling an FDI mechanism. As such, the impacts of an FTA on FDI are not captured. Finally, the data do not capture some of the nontariff measures and most of the barriers in trade in services. Because of these limitations, the use of the GTAP model may underestimate the real impacts of an FTA.

\subsubsection{The Data}

The main data come from the GTAP Database Release 5 (GTAP-5), which contains sixty-six countries/regions and fifty-seven sectors for 1997. ${ }^{8}$ The database provides production and consumption structures described in a social accounting matrix for each country. To facilitate the computation, the database is aggregated into twenty countries and twentyone sectors.

In the GTAP-5, trade barriers, which include tariff and nontariff measures, are described as the differences between domestic market prices and world market prices. Thus, the tariff and nontariff measures cover import tariffs, export subsidies, and domestic supports (output subsidies, intermediate input subsidies, land-based payments, and capital-based payments). ${ }^{9}$ However, the information on the barriers in service trade is still under development and does not cover many barriers. ${ }^{10}$ Hence, this paper focuses on merchandise trade, that is, agricultural, mining, and manufacturing trade, in analyzing trade flows.

\section{Trade Patterns of East Asian Economies}

Table 7.1 summarizes the export and import compositions of East Asian economies in 1997 from GTAP-5. Three distinct features are observed in this table. First, the major exports of many East Asian economies are textiles and machinery, especially electric equipment. Second, the major imports of many East Asian economies are concentrated in electric equipment and general machinery. Third, the shares of imports for agriculture and food products and beverages are larger than the corresponding export shares for all the economies except Vietnam. However, we should also note that most East Asian economies show low compositional shares in trade

7. Ianchovichina and McDougall (2000) develop a dynamic GTAP model based on the standard GTAP model.

8. For the GTAP-5, see Dimaranan and McDougal (2002).

9. In GTAP-5, zero rates are reported for antidumping duties, price undertakings, and voluntary export restraints (VERs) due to the absence of up-to-date data (Dimaranan 2002, 16A-11).

10. Because of the limited data availability, the number of sectors significantly decreases when we include the trade barriers in services in the CGE analysis. For a study that focuses on the trade barriers in services, see Brown and Stern (2001). 


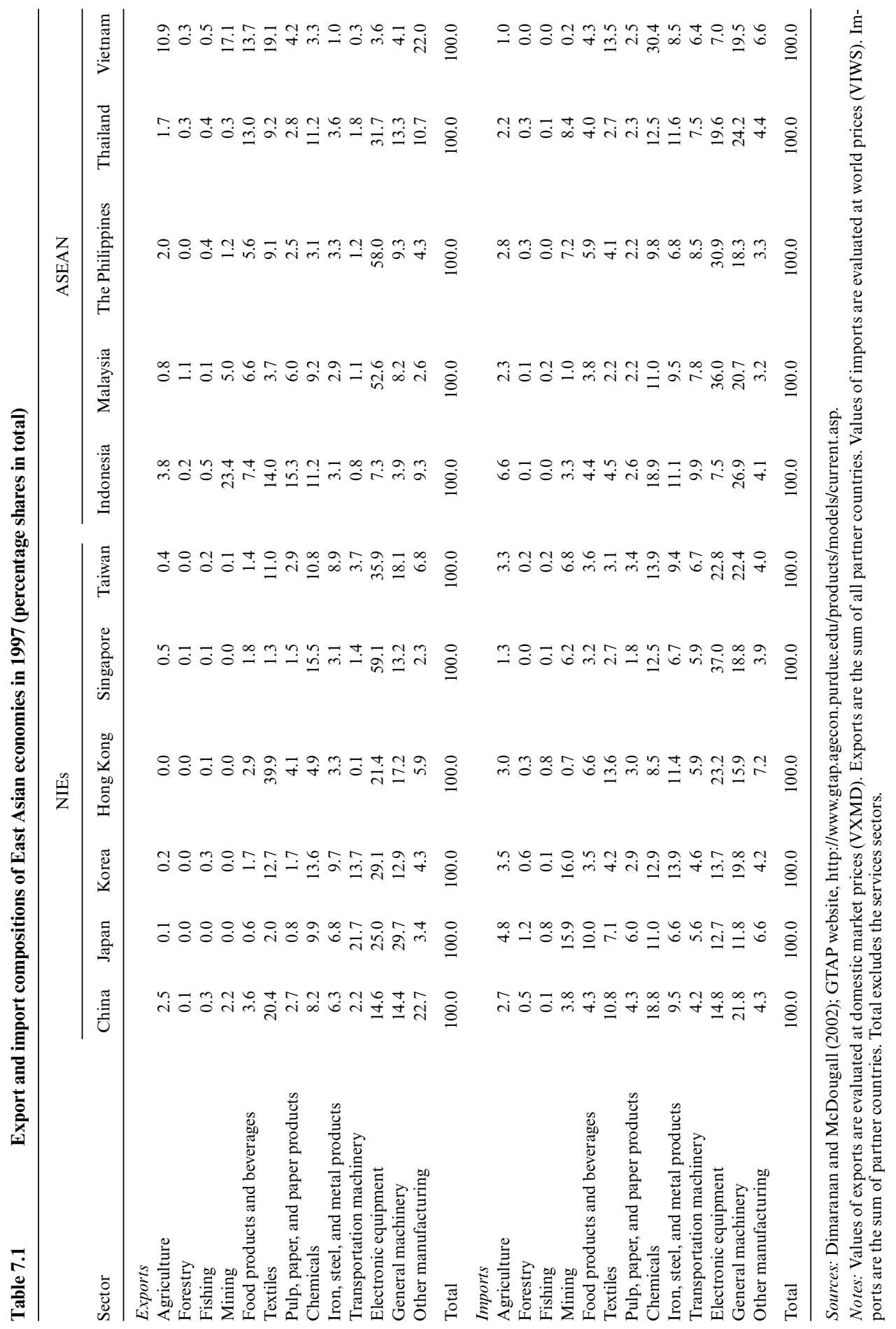


(exports and imports) for agriculture and food products and beverages except for Thailand and Vietnam for exports and Japan for imports.

Table 7.2 presents the intraindustry trade (IIT) patterns and revealed comparative advantage (RCA) for East Asian economies. ${ }^{11}$ The IIT index takes the value between 0 and 100, and it increases with the extent of intraindustry trade. The RCA takes the value greater than or equal to zero. If RCA for an industry for a country takes the value greater than unity, it is interpreted that the country has a comparative advantage in that industry. Similarly, if it takes the value less than unity, then the industry has a comparative disadvantage.

There are three notable findings in this table. First, for many economies, pulp, chemicals, and electronic equipment tend to show large figures for the IIT index. Second, most of agriculture, forestry, fishing, mining, and food products and beverages do not register large IIT figures. Third, the largest RCA is likely to be observed in electric equipment. Specifically, electric equipment represents the largest RCA figures for Japan, Korea, Singapore, Taiwan, the Philippines, and Thailand. The large numbers also appear in textiles and fishing. It is interesting to note that transportation machinery takes values greater than unity only for Japan and Korea, while general machinery takes values greater than unity only for Japan and Taiwan.

These observations indicate that many East Asian economies have a comparative advantage in the production of electric equipment, and many economies appear to engage in vertical division of labor in electronic equipment production. Specifically, many East Asian economies' competitiveness comes from labor-intensive assembling operations in the production of electronic equipment, as they import electronic parts and components to assemble finished products and export them to foreign countries.

Table 7.3 presents the three types of regionalization measures in terms of trade for East Asian economies. ${ }^{12}$ The absolute measure compares the scale of a particular intraregional trade relationship to world trade, while the relative measure compares it to its overall regional trade. The doublerelative measure, which is commonly called the trade intensity index, shows the intensity or bias of the intraregional trade relationship by taking into account its importance in world trade. The value of unity for the double relative measure can be interpreted so that the intraregional trade relationship is neutral, while the relationship is more (or less) biased when the measure is greater (or less) than unity.

The computed absolute measures show that intraregional trade in East Asia and ASEAN amount to 11 and 1 percent of world trade, respectively.

11. For the formulas used to compute the IIT index and RCA index, see the appendix.

12. The definitions of the three measures are given in the appendix. See Petri (1993) and Urata (2001) for the discussion of the regionalization measures and their application to East Asian economies. 


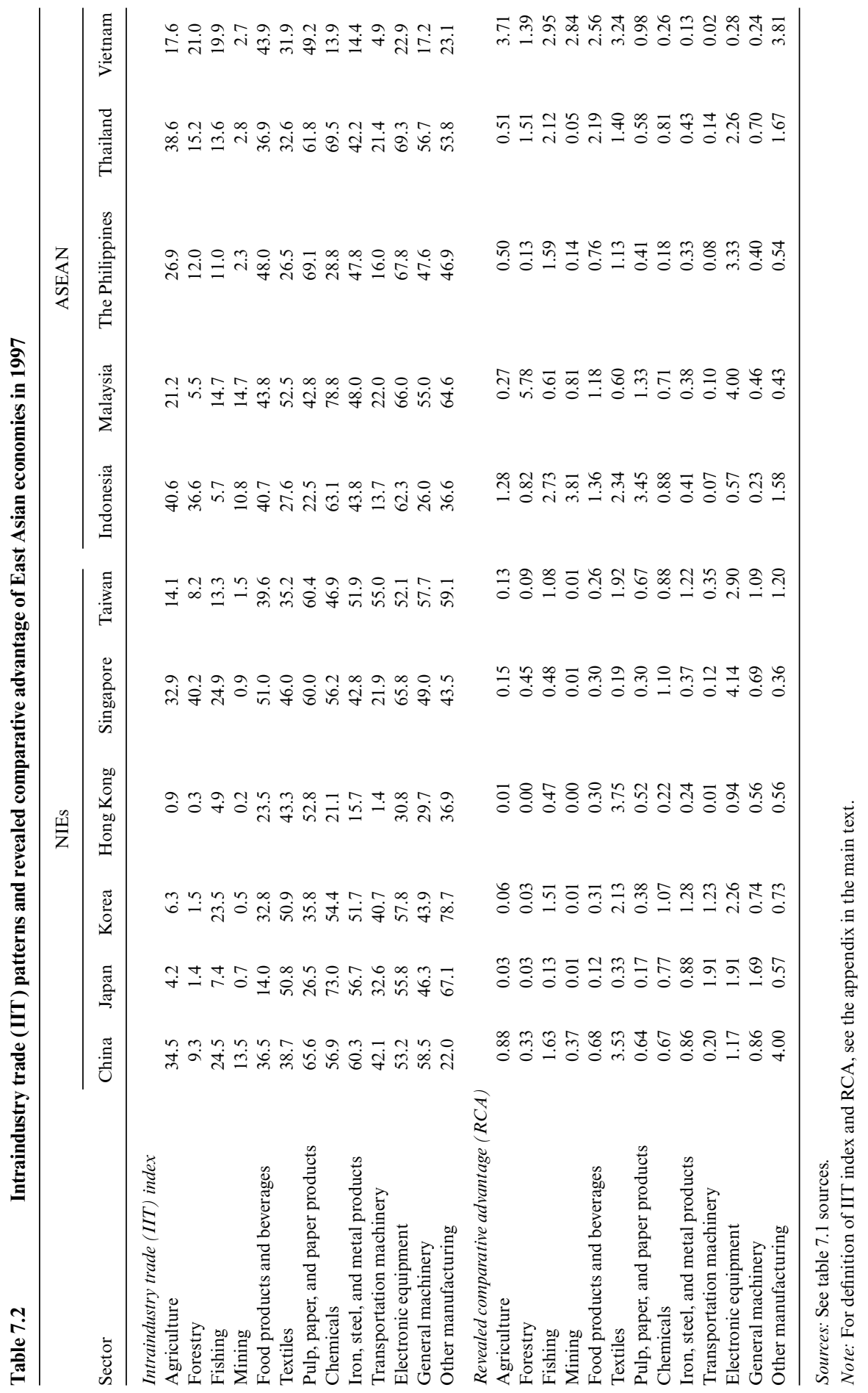




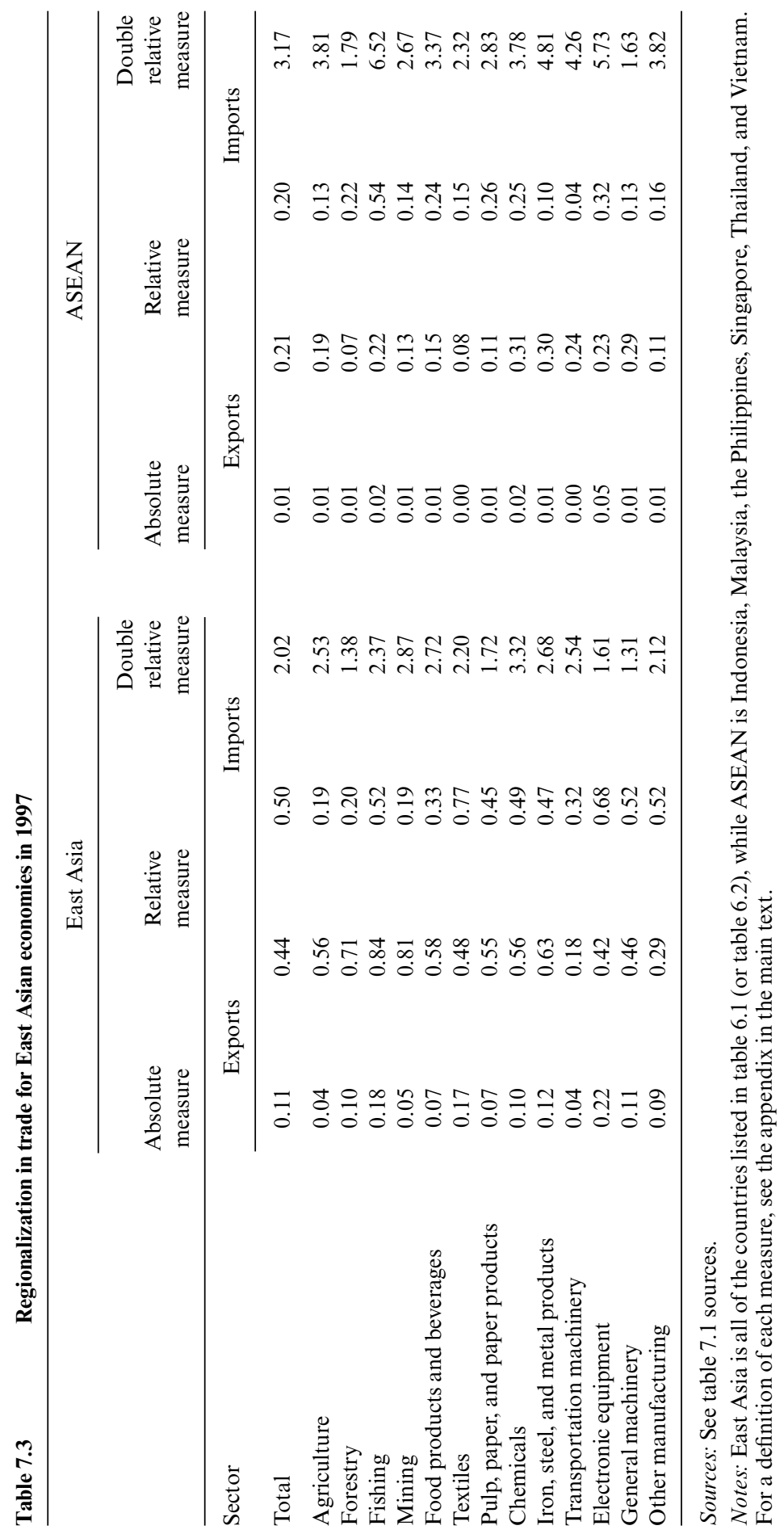


As to the relative measures, the share of intraregional exports in East Asia's exports was 44 percent, while the share of intraregional imports in East Asia's imports was larger, at 50 percent. These findings on the relative measures for exports and imports indicate that East Asia is an important source of imports rather than a destination of exports. The relative measures for exports and imports for ASEAN are 21 and 20 percent, respectively, significantly smaller compared with trade in East Asia. The ASEAN countries depend on non-ASEAN countries, particularly other East Asian countries, in their trade. The computed double-relative measures show that trade in both East Asia and ASEAN have strong intraregional bias. Intraregional bias is particularly strong for ASEAN trade, reflecting the presence of the AFTA, under which preferential treatment is given to intraASEAN trade.

The results for disaggregated-sector levels reveal several interesting developments. First, for electronic equipment, fishing, and textiles, intraregional trade in East Asia has a significant share in world trade, indicating that these products are actively traded in the region. Second, for electronic equipment and textiles, East Asia is an important source of imports rather than a destination of exports, reflecting the pattern of production and trade, in which parts and components are procured in East Asia to be assembled for the finished products in East Asia, which in turn are exported to outside the region. Third, high double-relative measures are observed for ASEAN trade vis-à-vis East Asia trade for all products except mining, indicating the influence of the AFTA on trade in a wide range of products.

\section{Nominal and Effective Rate of Protection for East Asian Economies}

In the GTAP database, trade barriers, which include tariff and nontariff measures, can be expressed as the difference in prices between domestic market prices and world market prices. We denote the difference as the nominal rate of protection (NRP). We also compute the effective rate of protection (ERP), which accounts for the protection on value added by taking into account the protection given not only to the product under study but also to intermediate inputs used for the product. ${ }^{13}$

Table 7.4 presents the calculated results of NRPs and ERPs from the GTAP database. There are three notable findings in this table. First, for China, Japan and Korea, the levels of protection on agriculture and food products and beverages are extremely high. The NRPs on food products and beverages are also high for these three countries and Taiwan. The results for China are somewhat surprising, as China exports substantial magnitudes of agricultural products, and food products and beverages.

Similarly, ERPs tend to be high for these industries in these countries with few exceptions, indicating that these industries are given substantial

13. The appendix explains the computational method of ERP. 


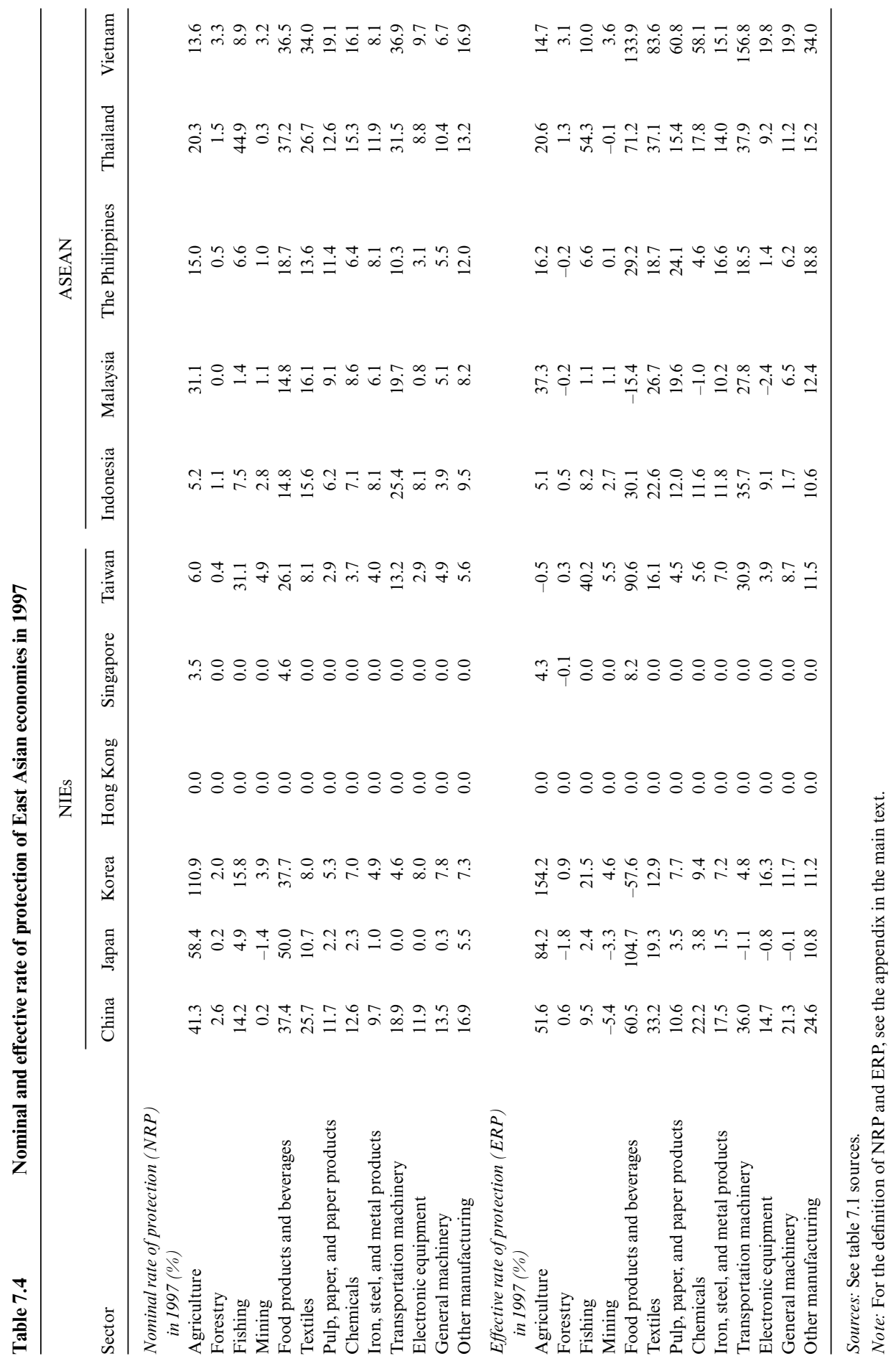


protection from import competition. Two exceptions are agriculture in Taiwan and food products and beverages in Korea, for which negative ERPs are obtained. These negative results are due to the fact that NRPs given to intermediate goods for the production of agriculture (in the case of Taiwan) and food products and beverages (in the case of Korea) are higher than NRPs given to agriculture and food products and beverages. In other words, agriculture in Taiwan and food products and beverages in Korea suffer from negative discrimination imposed by their governments.

Second, a high level of protection is given in paper, chemicals, and machinery industries in ASEAN countries as well as China, and these industries tend to represent larger figures for ERP than for NRP. Such patterns of protection, that is, higher ERP than NRPs, are common in many countries and characterized as tariff escalation. Indeed, tariff escalation is regarded as rational patterns of tariff protection for the development of a particular industry, although the effectiveness of such a policy appears questionable. It is to be noted that high protection is observed for the transportation machinery industry in many ASEAN countries and China, reflecting the importance of the industry for these governments.

Third, there are virtually almost no trade barriers in Hong Kong and Singapore. Only agriculture and food products and beverages receive protection, although the level of protection given to these industries by these governments is substantially lower when compared to the cases for other East Asian economies.

\subsection{Simulation Results}

We conducted a simulation analysis to discern the impacts of an East Asia FTA by removing trade barriers among East Asian economies. In this section we examine the results. We begin with the results for GDP and economic welfare in terms of equivalent variation $(\mathrm{EV})$ and then turn to the results on overall as well as sectoral outputs and trade.

Table 7.5 presents simulation results for GDP and EV for East Asian economies with a few selected countries. The results indicate that all FTA member economies obtain benefits from an East Asia FTA in terms of gross domestic product (GDP) and EV. The positive impacts are very large for the ASEAN countries. Among the ASEAN countries, Thailand gains substantially. Indeed, Thai GDP is estimated to increase as much as 16 percent from an East Asia FTA. The large gain for Thailand is attributable mainly to the high protection imposed on the Thai economy before an East Asia FTA. Vietnam and Indonesia also would gain substantially from an East Asia FTA.

By contrast to the gains accrued to the FTA members, nonmember countries experience negative impacts in the forms of declines in GDP and EV. These negative impacts are mainly attributable to the trade diversion 
Estimated effects of an East Asia FTA on real GDP and equivalent variation, for selected countries/regions

\begin{tabular}{|c|c|c|c|}
\hline & \multirow{2}{*}{$\begin{array}{c}\text { GDP } \\
\text { (changes from } \\
\text { base data, } \% \text { ) }\end{array}$} & \multicolumn{2}{|c|}{ Equivalent variation } \\
\hline & & $\begin{array}{c}\text { Changes from } \\
\text { base data (US\$ million) }\end{array}$ & $\begin{array}{c}\text { Changes divided by } \\
\text { GDP in } 1997(\%)\end{array}$ \\
\hline Australia/New Zealand & -0.23 & $-1,342$ & -0.29 \\
\hline China & 1.27 & 5,485 & 0.64 \\
\hline Hong Kong & 1.41 & 3,389 & 2.42 \\
\hline Japan & 0.05 & 8,199 & 0.19 \\
\hline Korea & 1.71 & 7,805 & 1.75 \\
\hline Taiwan & 1.51 & 5,597 & 1.87 \\
\hline Indonesia & 5.61 & 10,209 & 4.89 \\
\hline Malaysia & 2.83 & 2,279 & 2.15 \\
\hline The Philippines & 2.02 & 602 & 0.77 \\
\hline Singapore & 2.26 & 2,944 & 3.69 \\
\hline Thailand & 15.90 & 19,790 & 12.54 \\
\hline Vietnam & 8.42 & 1,446 & 6.61 \\
\hline Other Asia & -0.31 & $-1,803$ & -0.34 \\
\hline United States & -0.06 & $-7,059$ & -0.09 \\
\hline EU & -0.01 & $-1,807$ & -0.02 \\
\hline
\end{tabular}

Sources: See table 7.1 sources.

Note: Figures indicate the changes from base data.

effect from the East Asia FTA, by which nonmember countries' exports to East Asia are substituted by member countries' exports as a result of preferential treatment given to trade between the members. It should be noted that the negative impacts on the United States and the European Union (EU) are quite small while they are somewhat substantial for Australia/ New Zealand and Other Asia. Relatively large negative impacts for Australia/New Zealand and Other Asia stem from the fact that East Asia is a very important region for their export destination. Because the results of the simulation depend on the elasticity of substation between domestic and imported products, we examine how sensitive our results are to the size of elasticity by conducting a simulation with a 10 percent increase in the elasticity values. We found that the results are greater by approximately 10 percent, indicating the importance of the size of elasticities in determining the impacts of FTA. ${ }^{14}$

The impacts of an East Asia FTA on the changes in real outputs and real exports in agriculture and manufacturing sectors are presented in table 7.6. For Hong Kong, Singapore, Indonesia, Malaysia, the Philippines, and Thailand, positive impacts on real outputs are observed in almost all industries. One major exceptional sector is transportation machinery, whose

14. The results are not given in the paper, but they are available on request from the authors. 


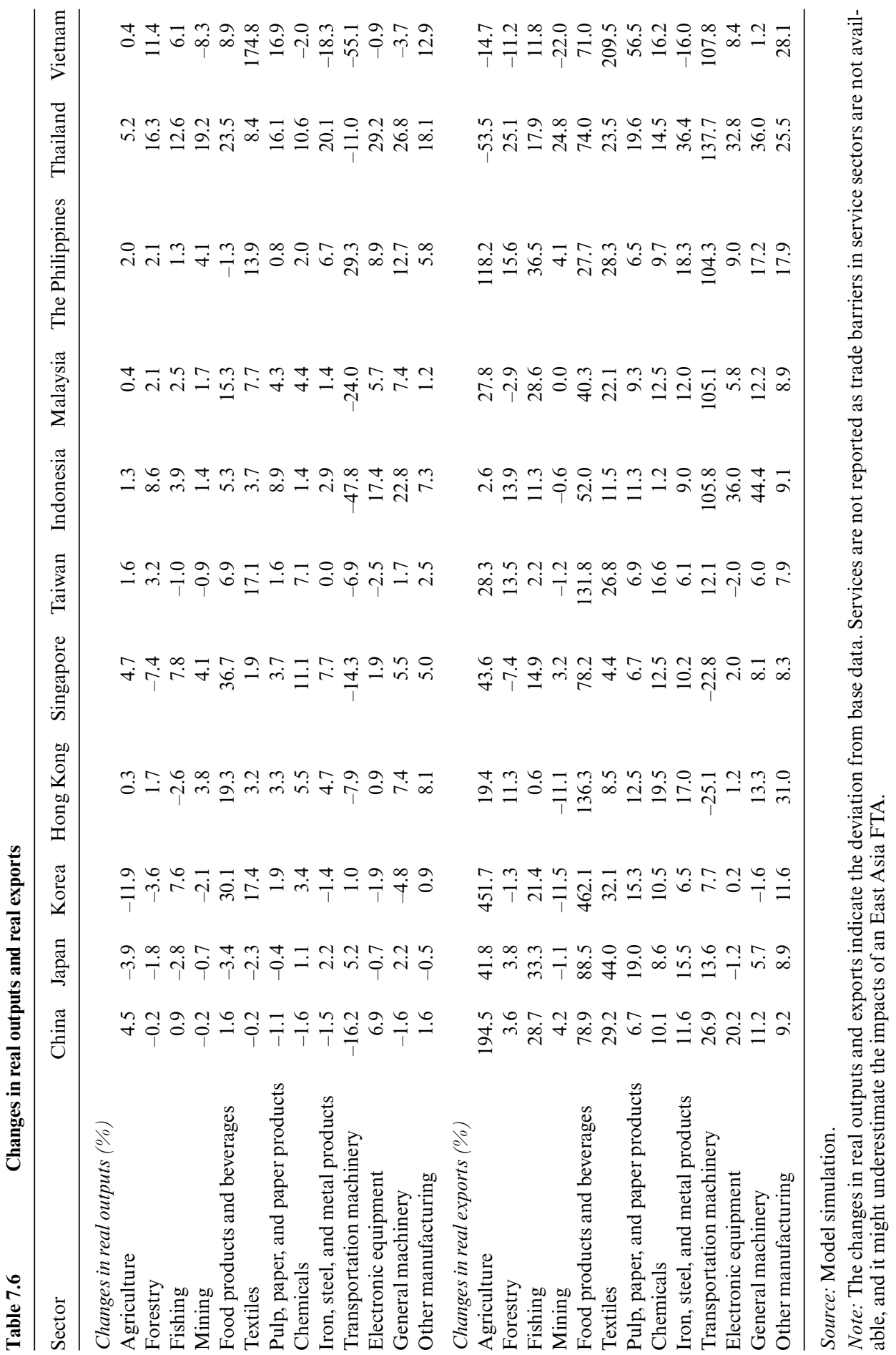


production declines for these economies except for the Philippines. Indeed, it should be noted that production of transportation machinery declines for all the economies except Japan and the Philippines. Unlike the case for many economies noted in the preceding, China, Japan, Korea, and Taiwan show sectoral variations in the direction of the changes in output.

Notable increases in output production are observed for the following sectors for the East Asian economies: agriculture (China, Singapore, and Thailand); food products and beverages (Korea, Hong Kong, Singapore, Malaysia, and Thailand); textiles (Korea, Taiwan, the Philippines, and Vietnam); electronic equipment (China, Indonesia, the Philippines, and Thailand); and general machinery (Indonesia, the Philippines, and Thailand). Some notable declines in output production are recorded as follows: agriculture (Japan and Korea); iron and steel (Vietnam); and transportation machinery (China, Singapore, Indonesia, Malaysia, Thailand, and Vietnam). These findings reveal the difficulty in establishing an East Asia FTA because of its negative impacts on the sectors with political influence in respective economies.

We have examined the impacts of an East Asia FTA on output at the sectoral level and found variations in its impacts among the sectors. It is of interest to examine if any systematic patterns exist in explaining the impact of an East Asia FTA among different sectors and economies. One would expect that the output of the sector that has a comparative advantage would increase more compared to that of the sectors with comparative disadvantage as a result of an FTA, because freer trade environment would give greater opportunities for output expansion for the sectors with comparative advantage. Along the similar line of the argument, one would expect that output of the protected sector would decline as a result of an FTA because of increased import competition. We examined these hypotheses by conducting regression analysis covering eleven economies and thirteen sectors. For the analysis, three different models are examined. The dependent variable, which is the same for the three models, is the rate of change in output, and explanatory variables are RCA, NRP, and ERP at base year, respectively. The results of the analysis support the first hypothesis, indicating that an FTA increases output of the sectors with comparative advantage (see table 7.7). However, they do not support the second hypothesis.

It is interesting to observe that exports increase for all the economies for almost all products with a few exceptions. Even exports of transportation machinery, whose production is shown to decline, are expected to increase for all of the economies except for Hong Kong and Singapore. These contrasting patterns of change in production and exports in transportation machinery reflect increased incentive given to exportation as a result of elimination of protection under the East Asia FTA. The sectors with substantial increases in exports include the following: agriculture (China, Japan, Korea, Singapore, and the Philippines); food products and beverages (all economies); textiles (Japan, Korea, and Vietnam); transportation 
Table 7.7

Relationship between protection, comparative advantage, and growth

\begin{tabular}{lcccccc}
\hline Dependent variable & \multicolumn{3}{c}{ Growth of outputs } & \multicolumn{3}{c}{ Growth of exports } \\
\hline Constant & $4.433^{* *}$ & $3.505^{*}$ & 0.640 & -2.931 & $19.300^{* * * *}$ & $36.810^{* * *}$ \\
& $(2.271)$ & $(1.939)$ & $(0.308)$ & $(-0.577)$ & $(3.093)$ & $(4.784)$ \\
NRP & 0.014 & & & $3.293^{* * *}$ & & \\
& $(0.123)$ & & & $(11.429)$ & & \\
ERP & & 0.066 & & & $(3.749 * * *$ & \\
& & $(1.184)$ & & & & -5.219 \\
RCA & & & $3.837^{* * *}$ & & & $(-1.028)$ \\
& 0.000 & 0.481 & 0.010 & 0.097 & 0.053 & 0.007 \\
$R^{2}$ & -0.007 & 0.477 & 0.003 & 0.090 & 0.046 & 0.000 \\
Adj. $R^{2}$ & 143 & 143 & 143 & 143 & 143 & 143 \\
$N$ &
\end{tabular}

Sources: NRP and ERP are from table 7.4. RCA is from table 7.2. The growth of outputs and exports are from table 7.6.

Note: $t$-statistics are in parentheses.

**** Significant at the 1 percent level.

**Significant at the 5 percent level.

*Significant at the 10 percent level.

machinery (Indonesia, Malaysia, the Philippines, Thailand, and Vietnam); electronic equipment (China, Indonesia, and Thailand); and general machinery (Indonesia and Thailand). One should note that these values are the rate of change, as such a large value may be partly due to the low initial value before the formation of an East Asia FTA. A case in point is agriculture and food products and beverages for Japan, for which large rates of export growth are expected partly because of low export value before the formation of an East Asia FTA.

Following the discussions on the determinants of the change in output in the preceding, we examine the determinants of the change in exports using the same framework. One would expect the sectors with a comparative advantage and the sectors with low protection to increase as a result of an East Asia FTA. The results show that exports of the sectors with high protection increase as a result of an East Asia FTA. This unexpected result can be explained by a shift of incentives from domestic sales to export sales because of the removal of protection. As to the relationship between RCA and export expansion, we could not detect the expected relationship.

The impacts of an East Asia FTA on export change lead to the changes in the composition of exports, which are shown in tables 7.8 and 7.9. The figures for 1997 indicate the export composition in 1997 (obtained from table 7.1) and those under FTA indicate the export composition after the simulation. Italic figures indicate the percentage changes between compositions in 1997 and those in FTA.

The results show that the impacts of an East Asia FTA are not large enough to change the composition of each economy's exports and imports 


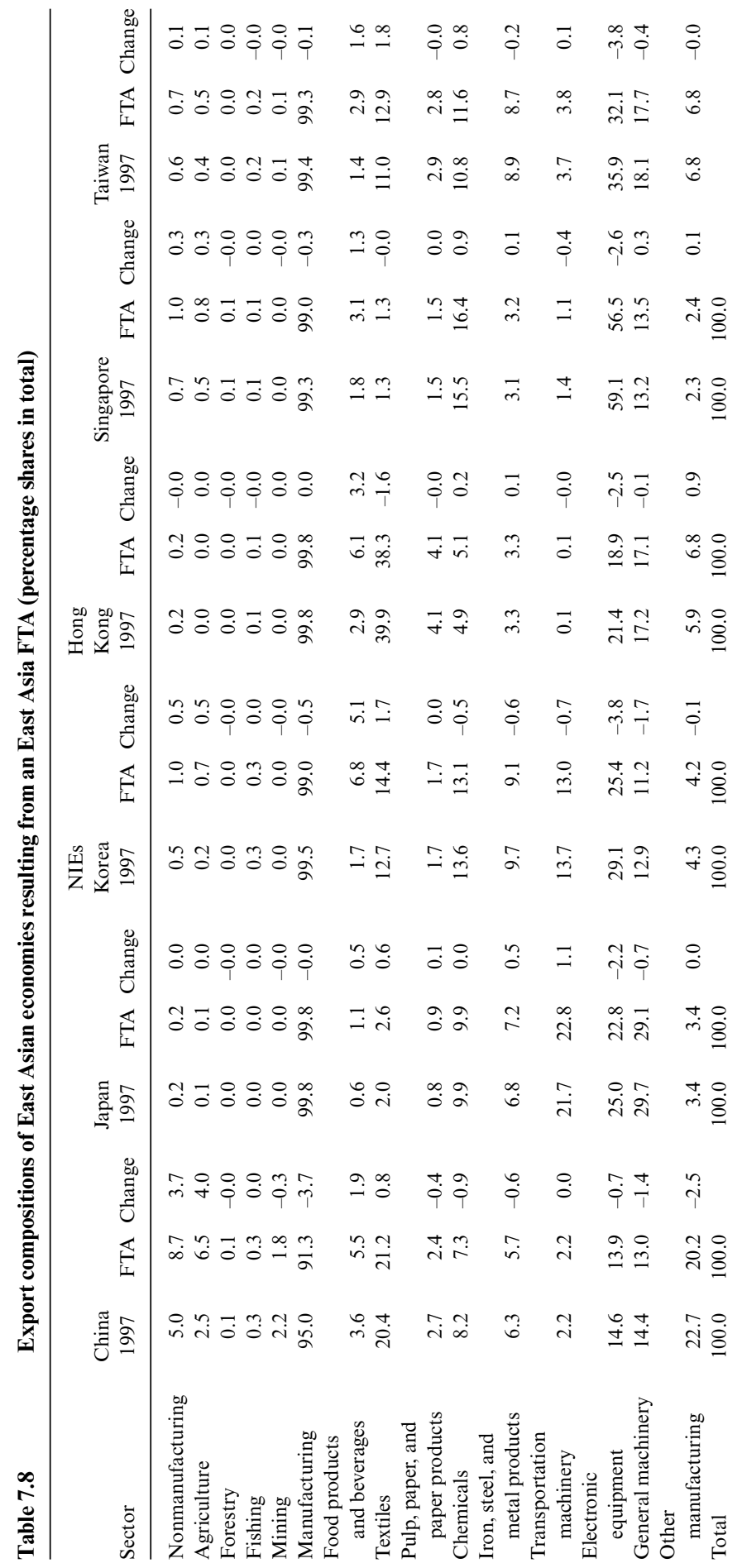




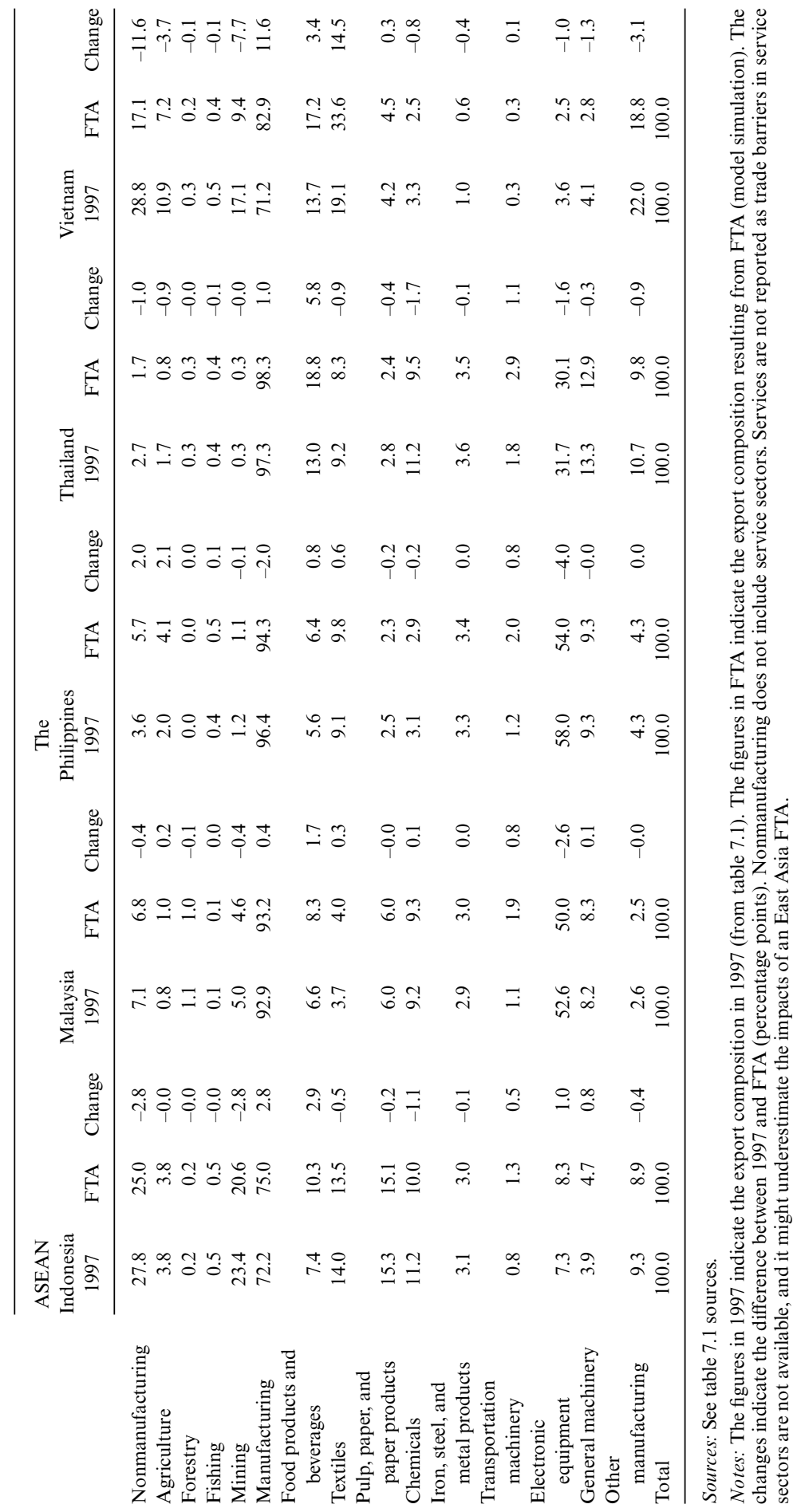




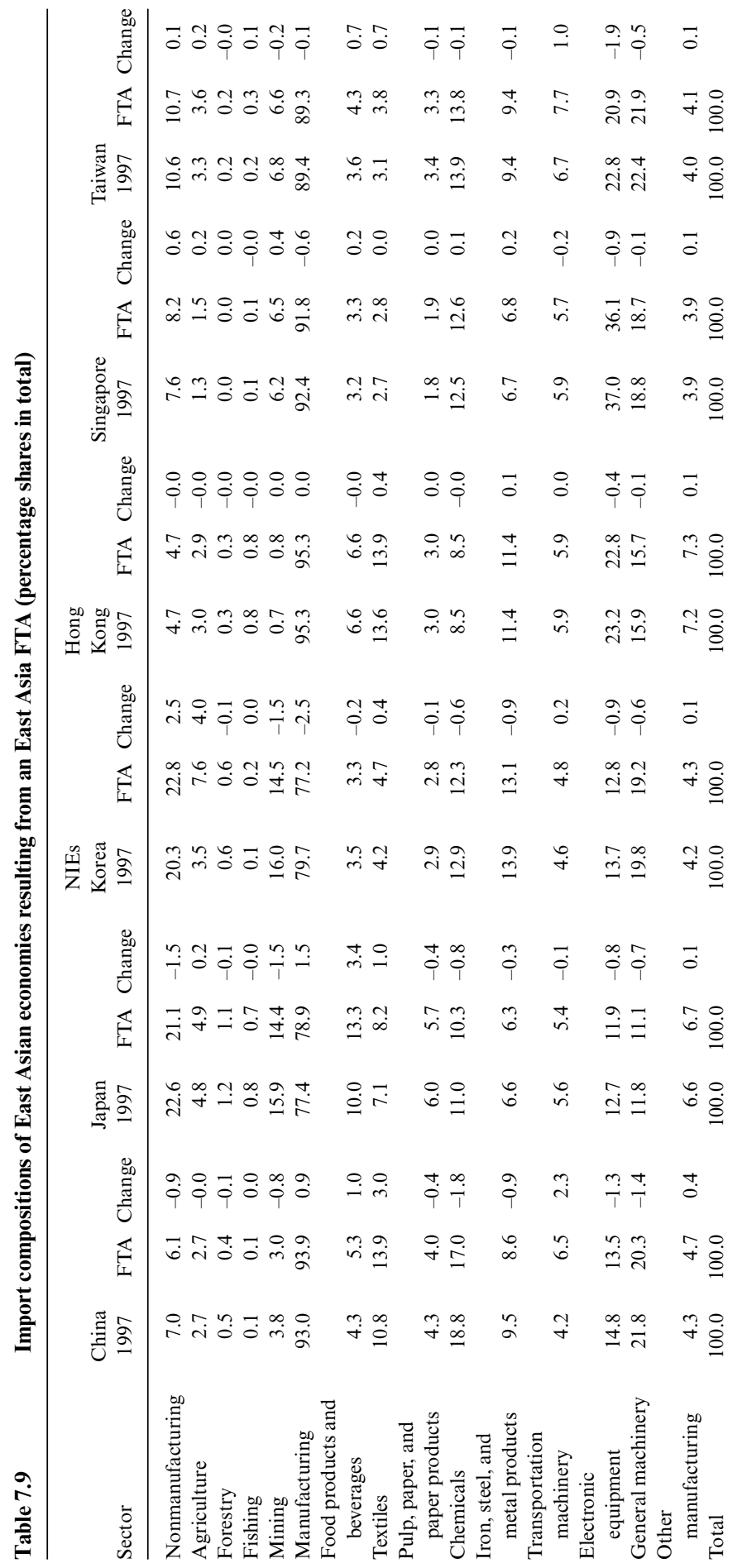




\begin{tabular}{|c|c|c|c|c|c|c|c|c|}
\hline 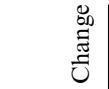 & 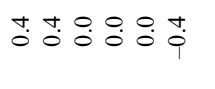 & 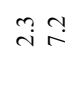 & $\stackrel{1}{\dddot{0}} \stackrel{0}{+}$ & $\stackrel{m}{T}$ & $\stackrel{0}{0}$ & $\hat{i} \stackrel{i}{i}$ & $\tilde{o}$ & \\
\hline$\overleftrightarrow{I}$ & 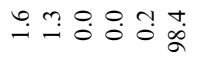 & $\ddot{b} \tilde{\dot{\theta}}$ & $\stackrel{\infty}{i} \underset{i}{i}$ & $\stackrel{n}{\sim}$ & $\stackrel{\infty}{i}$ & $\overrightarrow{6} \stackrel{?}{6}$ & 룽 & \\
\hline 兑合 & 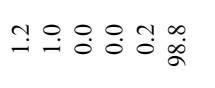 & $\stackrel{m}{\rightarrow} \stackrel{n}{m}$ & $\stackrel{n}{i} \underset{\dot{m}}{0}$ & 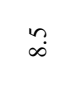 & $\vec{b}$ & $\stackrel{n}{r} \stackrel{n}{2}$ & ن용 & \\
\hline 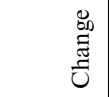 & 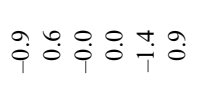 & $\stackrel{+}{-} \stackrel{\infty}{0}$ & ra: & $\hat{i}$ & $\dddot{m}$ & $\stackrel{9}{\rightarrow}$ & $\vec{i}$ & \\
\hline$\overleftrightarrow{I}$ & $\vec{\circ} \hat{i} \tilde{o} \overrightarrow{0} \stackrel{\circ}{\circ} \dot{\alpha}$ & 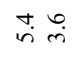 & iָ & $\grave{\varrho}$ & $\stackrel{\circ}{=}$ & 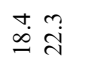 & $\stackrel{+}{+} \stackrel{0}{\stackrel{0}{0}}$ & \\
\hline 胥 & $\stackrel{\circ}{=}$ तี & 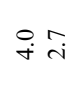 & min & $\stackrel{\circ}{=}$ & $\because$ & $\stackrel{\circ}{\stackrel{\sim}{\sim}}$ & $\stackrel{+}{+} \stackrel{0}{8}$ & \\
\hline $\begin{array}{l}\text { \& } \\
\text { Eี } \\
\text { Uే }\end{array}$ & $\vec{\varphi} \stackrel{m}{0} \stackrel{0}{0}: \stackrel{n}{0}: \overrightarrow{0}$ & $=?$ & $\because \stackrel{?}{9}$ & $\stackrel{0}{0}$ & $\stackrel{1}{9}$ & $\stackrel{\infty}{m} \stackrel{m}{\varphi}$ & $\overrightarrow{0}$ & \\
\hline$\overleftrightarrow{\xi}$ & $\vec{\circ} \vec{m} \ddot{0}: \overrightarrow{0} \dot{\circ}$ & $\stackrel{\circ}{r} \stackrel{n}{+}$ & $\begin{array}{r}\pi \\
\text { in }\end{array}$ & $\stackrel{\infty}{0}$ & $\stackrel{m}{\infty}$ & $\stackrel{\circ}{\dot{\infty}} \stackrel{\dot{\infty}}{-}$ & ஸ் & \\
\hline 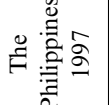 & 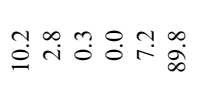 & $\dot{n} \bar{F}$ & הె & $\stackrel{\infty}{0}_{0}^{\infty}$ & $n$ & $\hat{\varnothing} \stackrel{m}{\infty}$ & m. & \\
\hline 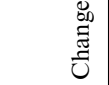 & 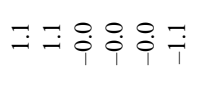 & $\stackrel{+}{\circ} \stackrel{0}{0}$ & $\overrightarrow{0} \stackrel{1}{0}$ & $\stackrel{t}{\dot{i}}$ & 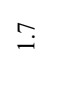 & तi & $\overrightarrow{0}$ & \\
\hline$\overleftrightarrow{I}$ & 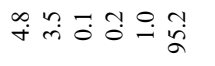 & $\underset{F}{\stackrel{0}{i}}$ & $\stackrel{\sim}{i} \stackrel{\infty}{0}$ & $\stackrel{\circ}{a}$ & $\approx$ & $\stackrel{\infty}{m} \stackrel{\infty}{\infty}$ & m. & \\
\hline 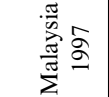 & 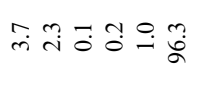 & $\stackrel{\infty}{r} \tilde{i}$ & તָ & $\tilde{a}$ & $\stackrel{\infty}{\sim}$ & $\dot{\vec{i}} \dot{\vec{i}}$ & సి. & \\
\hline 敢 & 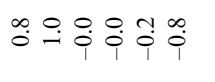 & $\hat{o} \hat{0}$ & $\because \stackrel{t}{0}$ & ชุ & $\stackrel{m}{i}$ & $n=$ & $\stackrel{\circ}{i}$ & \\
\hline$\overleftrightarrow{I}$ & 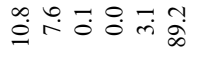 & in in & $\hat{i} \stackrel{n}{\infty}$ & $\stackrel{n}{=}$ & $\stackrel{\circ}{\circ}$ & $\stackrel{\infty}{i}$ 崩 & F官 & \\
\hline 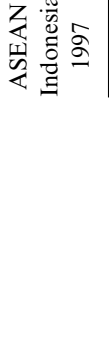 & 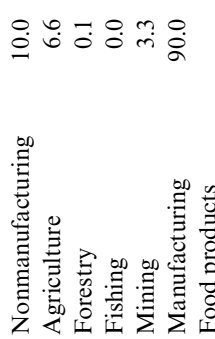 & 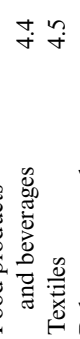 & 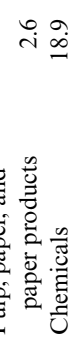 & 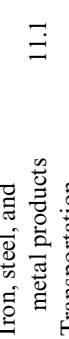 & 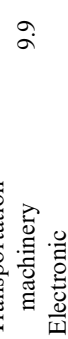 & 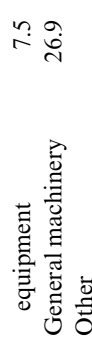 & 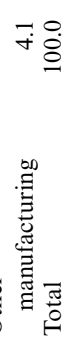 & 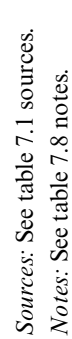 \\
\hline
\end{tabular}


substantially. ${ }^{15}$ Specifically, the changes in exports with more than 5.0 percentage points are confirmed for only a few sectors, such as mining in Vietnam, food products and beverages in Korea and Thailand, and textiles in Vietnam. For other sectors and economies, the magnitudes of the changes are less than 5.0 percentage points, most of which are less than 1.0 percentage point.

An analysis of the impacts of an East Asia FTA on the intraindustry trade pattern is of interest. One would argue that an FTA may expand intraindustry trade because enlarged regional market resulting from the elimination of trade barriers gives greater trade opportunities for differentiated products. However, the results shown in table 7.10 do not support this argument, as more than half of the cases, specifically 73 cases out of 143 cases (eleven economies and thirteen sectors), show a minus sign, reflecting the decline in the intraindustry trade.

We now turn to the impacts of an East Asia FTA on regional trading patterns. Table 7.11 presents the regionalization indexes for East Asia and ASEAN countries. The results indicate that for overall trade all three regionalization measures increase for East Asia as a result of an East Asia FTA. These observations, which appear to reflect that the trade diversion effect is greater than the trade creation effect, indicate that the establishment of the FTA promotes regionalization. This result is consistent with our expectation because an FTA is a trade arrangement, which treats the members preferentially and nonmembers discriminatorily. Contrary to the case for East Asia as a whole, intraregional trade bias declines for ASEAN, although the absolute and relative measures of regionalization increase. This finding indicates that for ASEAN, extra-ASEAN trade expands faster than intra-ASEAN trade.

At the sector level, for almost all sectors absolute and relative measures increase as a result of an East Asia FTA. This means that the importance of intraregional trade in East Asia and AFTA countries increase with respect to world trade as well as their own trade. The rates of change are particularly high for agriculture, food products and beverages, and transportation machinery for East Asia. Unlike the patterns observed for the absolute and relative measures, the rates of change for the double-relative measure are not uniform. For East Asian trade, large increases in regional bias are observed for agriculture, pulp, paper and paper products, and general machinery, while a notable decline is observed for chemicals. For ASEAN countries many products show a decline in bias with notable exceptions for agriculture and general machinery. These results imply that an East Asia FTA promotes the regionalization within East Asia, and it

15. It should be added that an East Asia FTA does not change the patterns of RCA significantly, as can be expected from small changes in the compositions of exports. The RCA figures under an East Asia FTA are available from the authors on request. 


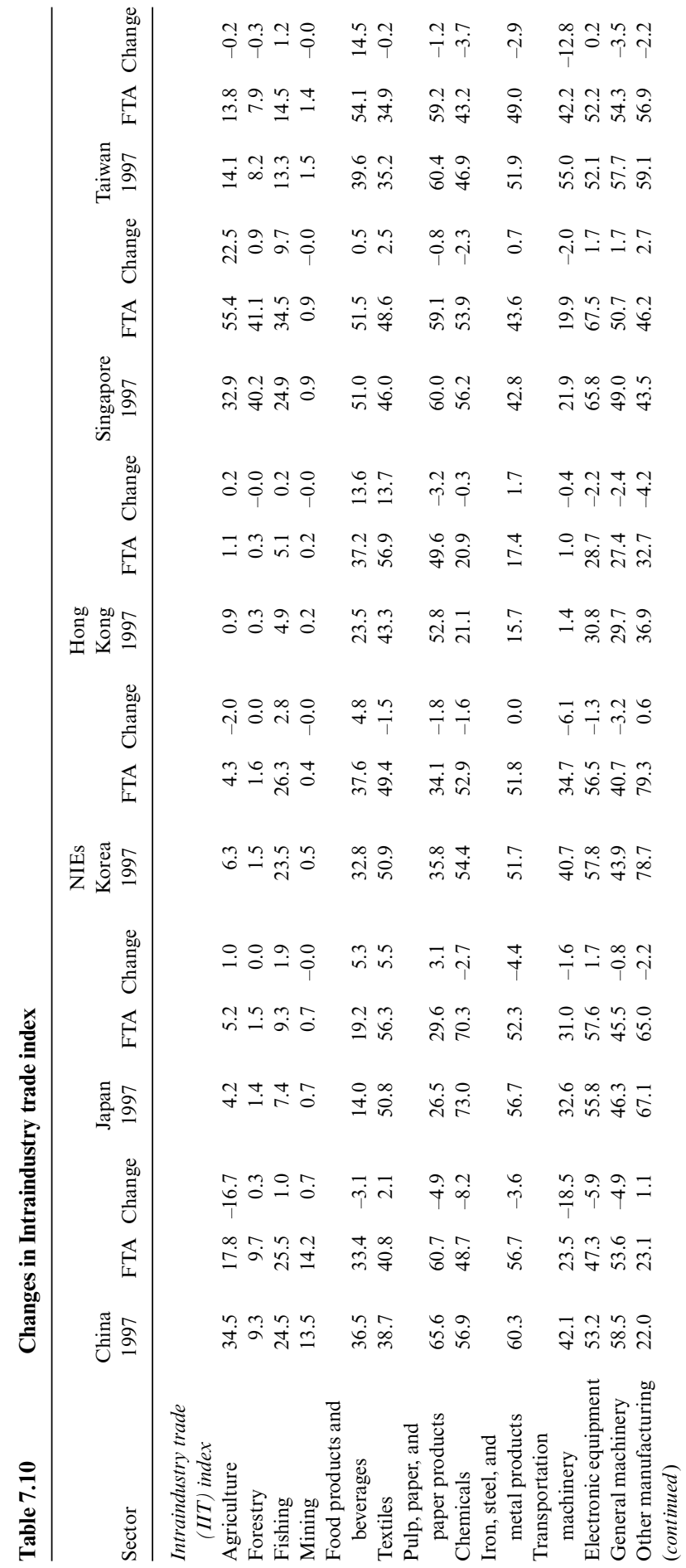




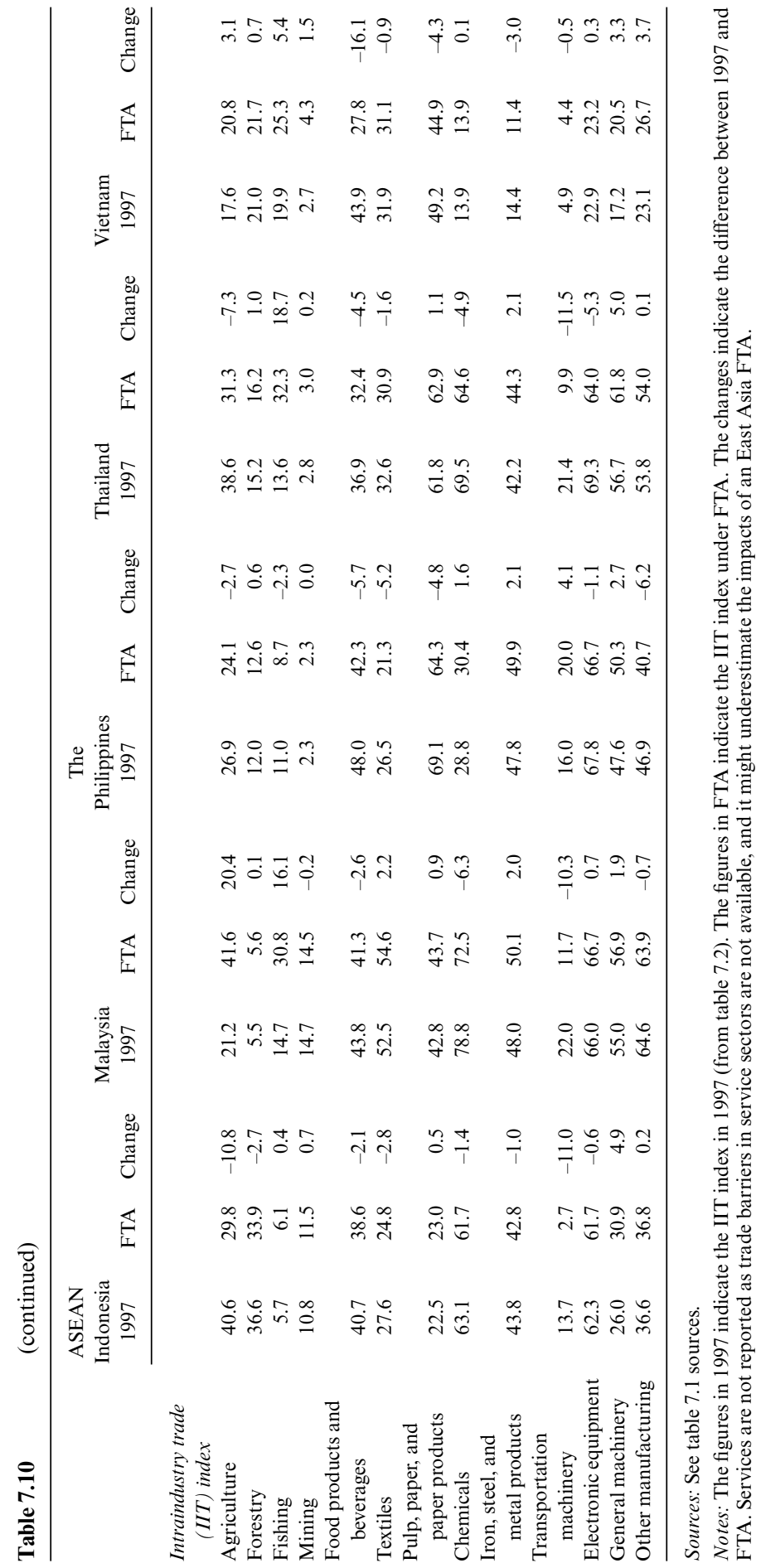




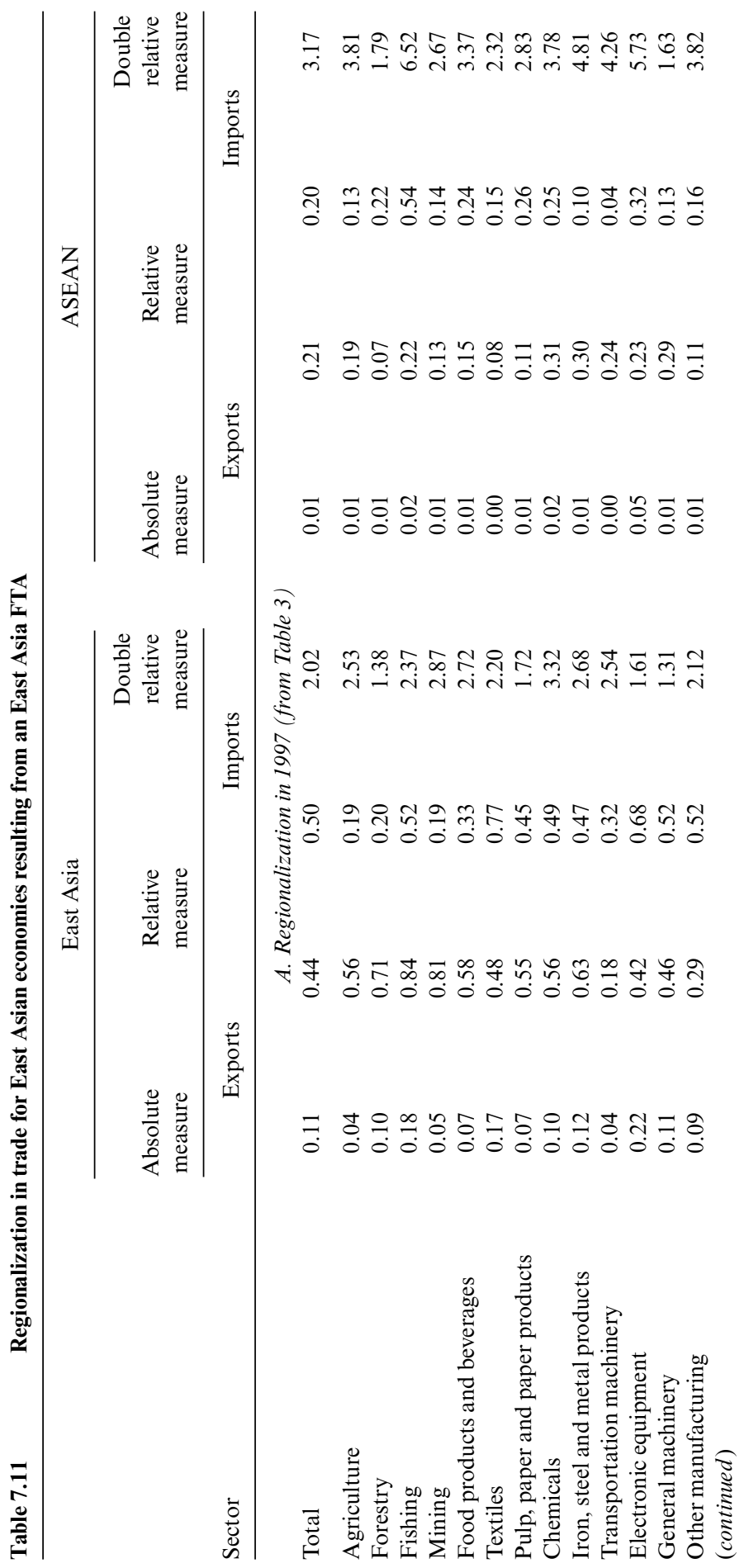




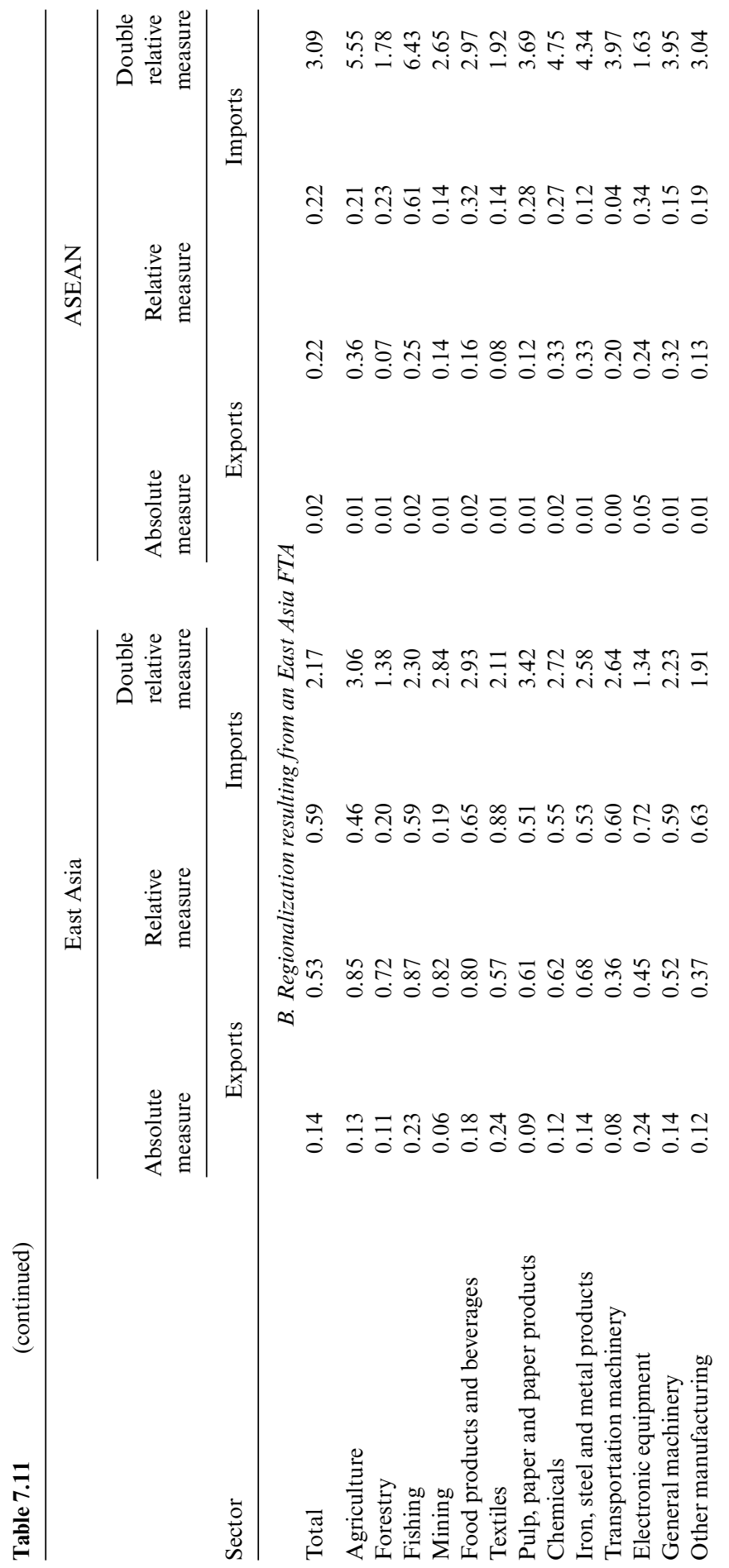




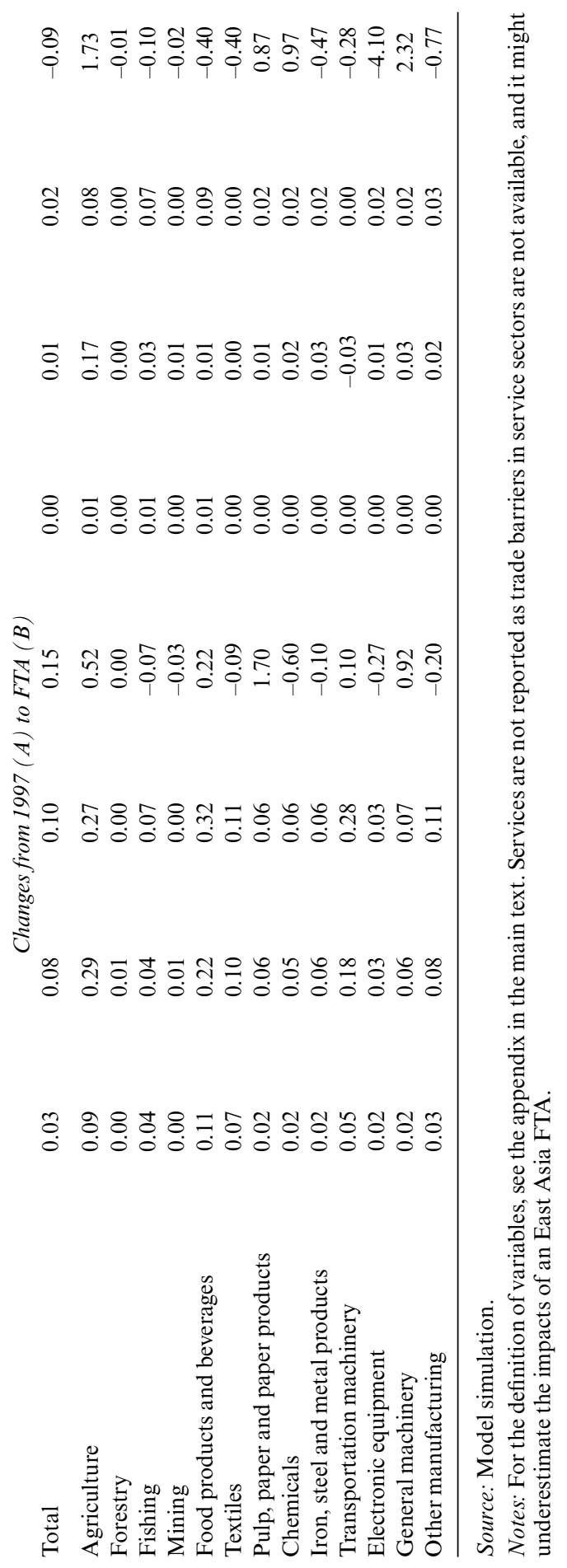


encourages ASEAN countries to have closer relationships with other East Asian economies.

\subsection{Conclusions}

In light of increasingly strong interest in FTAs and an East Asia FTA among many East Asian economies, we investigated the economic impacts of an East Asia FTA on East Asian economies with a focus on trade patterns by conducting a simulation analysis utilizing a CGE model. We found that an East Asia FTA brings positive impacts to East Asian economies in terms of economic growth and economic welfare. As to its impacts on trade patterns for East Asian economies, the simulation results show relatively small impacts, but they reveal some interesting patterns. We found that the sectors with a comparative advantage increase output and those with strong protection increase exports. The former relationship is expected, but the latter finding is not consistent with the expectation.

One explanation for this unexpected result is that an FTA shifts an incentive from domestic sales to export sales for protected sectors. Although exports of many sectors would increase as a result of an East Asia FTA, output production of some sectors is likely to decline. These potentially impacted sectors oppose an East Asia FTA. To overcome such opposition and to establish an East Asia FTA, financial and technical assistance should be given to potentially impacted workers to ameliorate the costs of adjustment. An East Asia FTA is found to promote regionalization in trade in East Asia, partly at the cost of exports from outside the region. Indeed, it has negative impacts in terms of economic growth and welfare on nonmembers. These findings argue strongly for the need to pursue worldwide trade liberalization under the WTO. Indeed, the formation of an East Asia FTA has to be regarded as a step toward multilateral liberalization.

We have examined the impacts of an East Asia FTA on trade patterns in East Asia by using a CGE model. Our results present useful information on the likely impacts of such an FTA. However, we do realize some shortcomings. First, there are some features of FTAs that could not be incorporated satisfactorily in our model, and we need to devise ways to incorporate them more satisfactorily. They include rules of origin, FDI, technology transfer associated with FDI, international labor mobility, and others. Besides the issues related to the simulation model, which is constructed at the sector level, we also realize the need to investigate the likely impacts of FTAs at the firm level to discern the detailed impacts of FTAs. As the availability of firm-level data has become better in recent years, researchers should analyze the impacts of trade liberalization on firms' trading behavior to draw some implications on the impacts of FTAs. Finally, we strongly hope that our results will be used for policy discussions on an East Asia FTA. 


\section{Appendix}

\section{Definitions of Variables}

\section{Regionalization Index}

We use three types of regionalization index. The first index is called absolute measure and is defined as

$$
A=\frac{x_{j k}}{\sum_{k} \sum_{j} x_{j k}}
$$

where $j$ and $k$ indicate home and partner countries, respectively. $x_{j k}$ represents exports from country $j$ to country $k$, respectively. Therefore, absolute measure captures the export share of country $j$ to country $k$ relative to world total exports.

The second index is called relative measure, which is defined as

$$
B=\frac{A}{\frac{\sum_{k} x_{j k}}{\sum_{k} \sum_{j} x_{j k}}}=\frac{x_{j k}}{\sum_{k} x_{j k}} .
$$

The relative measure indicates the export share of country $j$ to country $k$ relative to country $j$ 's total exports.

The third index is called double-relative measure. Double-relative measure is the export share of country $j$ to country $k$ divided by home and partner export shares so that we could partly control both home and partner's scale.

$$
C=\frac{A}{\left(\frac{\sum_{k} x_{j k}}{\sum_{k} \sum_{j} x_{j k}}\right)\left(\frac{\sum_{j} x_{j k}}{\sum_{k} \sum_{j} x_{j k}}\right)}=\frac{x_{j k} \times \sum_{k} \sum_{j} x_{j k}}{\sum_{j} x_{j k} \times \sum_{k} x_{j k}}
$$

The value of exports is evaluated at the domestic market price while value of imports is evaluated at the world price.

\section{Intraindustry Trade (IIT) Index}

The intraindustry index is defined as

$$
\operatorname{IIT}_{i j}=\left(1-\frac{\sum_{k}\left|x_{i j k}-m_{i j k}\right|}{\sum_{k}\left(x_{i j k}+m_{i j k}\right)}\right) \times 100,
$$

where $i, j$, and $k$ indicate industry, home country, and partner country, respectively. $x_{i j k}$ and $m_{i j k}$ represent exports and imports of industry $i$ in country $j$ to country $k$, respectively. The IIT index takes a value between 0 and 
100. The larger the index, the larger the intraindustry trade will be. The value of exports is evaluated at the domestic market price while the value of imports is evaluated at the world price.

Note that the definition of the IIT index in the GTAP model is different from that of a Grubel-Lloyd type IIT index. The former is differentiated across countries in the same industry. The latter is differentiated across subindustries (or detailed level of industries) in the same industry.

\section{Revealed Comparative Advantage (RCA)}

RCA is defined as

$$
\mathrm{RCA}_{i j}=\frac{\frac{x_{i j}}{\sum_{i} x_{i j}}}{\frac{\sum_{j} x_{i j}}{\sum_{j} \sum_{i} x_{i j}}},
$$

where $i$ and $j$ indicate industry and home country, respectively. $x_{i j}$ represents exports of industry $i$ in country $j$ to the world and evaluated at domestic market price. Therefore, $\mathrm{RCA}_{i j}>1$ means that industry $i$ in country $j$ has comparative advantage (compared with world average) while $\mathrm{RCA}_{i j}$ $<1$ means $i$ in country $j$ has comparative disadvantage.

\section{Nominal Rate of Protection (NRP)}

The rate of protection in imports is defined as

$$
t_{i j}=\frac{\left(m_{i j}^{M}-m_{i j}^{W}\right)}{m_{i j}^{W}},
$$

where $i$ and $j$ indicate industry and home country. $m_{i j}^{M}$ and $m_{i j}^{W}$ are the values of imports evaluated at the domestic market price and at the world price, respectively. Hence, the rate of protection in imports includes both tariff barriers and nontariff measures.

\section{Effective Rate of Protection (ERP)}

We define ERP as follows:

$$
\operatorname{ERP}_{i j}=\frac{t_{i j}-\sum_{z} t_{m j} a_{i z j}}{1-\sum_{z} a_{i z j}},
$$

where $i, z$, and $j$ indicate final goods industry, intermediate goods industry, and home country, respectively. $a_{i z j}$ indicates the input coefficient from industry $z$ to $i$ in country $j$ obtained from the input-output table in the GTAP database. $t_{i j}$ is the NRP defined as in the preceding. The rate of protection in this analysis, therefore, includes both tariff and nontariff barriers. 


\section{References}

Ballard, Charles L., and Inkyo Cheong. 1997. The effects of economic integration in the Pacific Rim: A computational general equilibrium analysis. Journal of Asian Economics 8 (4): 505-24.

Brown, Drusilla K., Kozo Kiyota, and Robert M. Stern. 2004. Computational analysis of the U.S. bilateral free trade agreements with Central America, Australia, and Morocco. RSIE Discussion Paper no. 507. Ann Arbor: Research Seminar in International Economics, University of Michigan.

Brown, Drusilla K., and Robert M. Stern. 2001. Measurement and modeling of the economic effects of trade and investment barriers in services. Review of International Economics 9 (2): 262-86.

Dimaranan, Betina V. 2002. Construction of the protection data base. In Global trade, assistance, and production: The GTAP 5 data base, ed. Betina V. Dimaranan and Robert A. McDougall, 16-A-1-16-A-12. West Lafayette, IN: Center for Global Trade Analysis, Department of Agricultural Economics, Purdue University.

Dimaranan, Betina V., and Robert A. McDougall, eds. 2002. The GTAP 5 data base. West Lafayette, IN: Center for Global Trade Analysis, Department of Agricultural Economics, Purdue University.

Hertel, Thomas W., ed. 1997. Global trade analysis: Modeling and applications. Cambridge, UK: Cambridge University Press.

Ianchovichina, Elena, and Robert McDougall. 2000. Theoretical structure of dynamic GTAP. GTAP Technical Paper no. 17. West Lafayette, IN: Center for Global Trade Analysis, Department of Agricultural Economics, Purdue University.

Petri, Peter A. 1993. The East Asian trading bloc: An analytical history. In Regionalism and rivalry: Japan and the United States in Pacific Asia, ed. Jeffrey A. Frankel and Miles Kahler, 21-48. Chicago: University of Chicago Press.

Urata, Shujiro. 2001. Emergence of an FDI-trade nexus and economic growth in East Asia. In Rethinking the East Asian miracle, ed. Joseph Stiglitz and Shahid Yusuf, 409-60. New York: Oxford University Press.

2002. A shift from market-led to institution-led regional economic integration in East Asia. Paper presented at the RIETI international conference, Asian Economic Integration. 22-23 April, Tokyo, Japan.

\section{Comment Dukgeun Ahn}

This article addressed very timely one of the most contemporary trade issues for East Asian countries. As explained by authors, the East Asian countries not conventionally enthusiastic about regional trading arrangements have recently been eager to establish divergent forms of FTAs. The very first free trade arrangement (FTA) in East Asia already entered into force between Japan and Singapore. Japan is now working on a FTA with Mexico. Korea is also about to ratify its first FTA with Chile and will soon

Dukgeun Ahn is director of the WTO and Trade Strategy Center at the Korea Development Institute (KDI) School of Public Policy and Management. 
begin an FTA negotiation with Singapore. After signing a framework agreement on comprehensive economic cooperation with the Association of Southeast Asian Nations (ASEAN), China has been undertaking FTA negotiations to conclude by June 2004. It is also expected that Korea and Japan formally start FTA negotiation at least by early next year. Policymakers as well as academics discuss even the prospect of a trilateral FTA, including Korea, Japan, and China, or comprehensive economic cooperation encompassing the entire ASEAN+3 (China, Japan, and Korea). All these developments would substantially change trade politics in the world trading system. In that regard, the analysis in this article made an important contribution by attempting empirical assessment on economic effects of an East Asia FTA.

Using a simulation analysis, the authors conjectured that gross domestic product (GDP) growth and equivalent variation (EV) would increase although the magnitudes of increases might not be significant for most East Asian countries. They also found that trade structures and composition of East Asian countries would not be substantially affected by an East Asian FTA, while regionalization among them would tend to be intensified. In addition, they concluded that the expected growth in exports would be larger in sectors with stronger protection. These interesting assessments may be qualified by incorporating some of subsequent factors.

First, the simulation model employed by the authors basically depicts the world in 2010, in which they anticipated, inter alia, the abolition of the Multifiber Agreement (MFA) and incorporation of the North American Free Trade Agreement (NAFTA), Japan-Singapore Economic Partnership Agreement (JSEPA), and the ASEAN Free Trade Area (AFTA). Considering various major FTA negotiations in the East Asian region, the simulation model may be extended to incorporate more FTAs, for example, between China-ASEAN, Japan-Mexico and Korea-Chile, which are all plausibly envisioned to be in force by 2010 .

Second, the simulation model may reflect one of the most common features of the recent FTA arrangements - that parties to FTAs typically make concessions and commitments beyond the scope of the WTO. The FTAs negotiated after the inception of the WTO normally include "WTO plus" commitments in various areas, such as investment, trade in serviceparticularly, movement of natural persons, trade facilitation, trade remedy system, intellectual property protection, and a range of economic cooperative measures. When this commonality is reflected in the model, the positive effect of an East Asia FTA would be sizably augmented.

Third, despite impressive data management for statistical testing and meticulous empirical modeling by the authors, the empirical results show some abnormal assessment for certain variables. For example, in table 7.11, real exports for the Korean "food products and beverage" and agricultural sectors appear to grow most - by 15.8 percent and 15.5 percent, respectively - among all industry sectors of East Asian countries when an East 
Asia FTA is established. This result does not comply with most economic forecasts or explanation. It would require more compelling economic explanations or recalibration of some data.

Fourth, the authors concluded that the expected growth in exports would be larger with an East Asia FTA as the existing protection level was higher. They also explained that this result was caused by incentive shifts for producers to export rather than sell in domestic markets as a result of removal of protection. This rationale, however, does not explain why the removal of protection is necessarily linked to increased export. In other words, removal of high tariffs for agricultural sectors in Japan would not suddenly create incentives or ways for Japanese farmers to export more when they face more fierce competition in domestic markets. Maybe a more compelling explanation for this relationship is the reciprocal nature of protection levels. Normally, when one country maintains high protective measures for particular sectors, its trading partners are more likely to have similar protection in those industry sectors. Because FTA negotiations are conducted mostly on the basis of reciprocity, dismantling those protective measures in one country would be more likely to induce or be accompanied by equivalent elimination of protection. In that sense, there may be a possibility to promote more trade in more protected sectors, albeit no guarantee for increased exports.

Last, the empirical finding that FTA benefits are compromised with the existence of adjustment costs representing friction of labor mobility reinforces the importance of the trade adjustment assistance (TAA) program in terms of trade policy. The United States has somewhat extensive experience of using TAA programs to facilitate labor adjustment when substantial trade liberalization demands unbearable industry restructuring, at least in the short term. The Trade Act of 2002 to accommodate Doha Round negotiation again stipulates elaborated TAA programs. Although the TAA programs implemented by the U.S. government have not been particularly successful, trade policy measures in line with the TAA programs would be necessary for East Asian countries to address convoluted policy coordination and properly realign conflicting economic interests.

\section{Comment Erlinda Medalla}

Let me start by congratulating the authors for the insightful paper. The paper is well focused, and they presented substantial key findings without inducing information overflow.

I have already indicated in my comments to the earlier paper about my

Erlinda Medalla is a senior research fellow of the Philippine Institute for Development Studies. 
preference for using the computable general equilibrium (CGE) approach to analyze the impact of regional trade agreements (RTAs).

I wish, however, that there was more explanation about the exact model used, so the reader, especially those unfamiliar with the Global Trade Analysis Project (GTAP) model, would have a greater understanding of how it works. Perhaps there should be an appendix that provides the equations used and the list of parameters and assumptions employed. Perhaps, in the paper itself, there could be a diagram illustrating the framework and the workings of the model. The part on the description of the model (section 7.3.1) could certainly do with a bit more elaboration.

Despite the limitations of the CGE approach, which the earlier paper alluded to and that the authors also point out, I think it is still one of the best methods of assessing the impact of RTAs, especially RTAs that are still being formulated.

Of course, considering that in the new age partnership, the other elements (outside-goods trade liberalization) are probably equally (if not more) important, one wishes for more than what presently the model could do. And indeed, in their conclusion, they point to the need for designing new ways to incorporate these other elements more satisfactorily.

Having pointed out these limitations, the only other things to watch out for are the data used, the assumptions used, and the interpretation of the results.

I have no questions about the data used. My questions are more on the assumptions.

\section{On the Simulation Scenarios}

In constructing the standard scenario, the paper projected growth in factors of production from 1997 to 2010, among other things (which built-in key agreements made). The inherent assumption is that these would be the same regardless of the formation of the RTA. Supposedly, the growth rates of these factors would be what would be without the formation of the RTA being assessed (the East Asia FTA). The paper presents the basis for the estimates of the growth in population in skilled-unskilled labor. But what about capital? How was the standard scenario estimated? This was not made clear in the paper.

The GTAP model would then supposedly simulate the standard scenario on GNP, allocation among countries, and so on - the works. In the process, are identities maintained? Equilibrium conditions are, of course, supposed to be maintained. But what happens to accounting identities and initial conditions? For example, does the system go back to the initial trade balance for individual countries or maybe just the global balance, with exchange rate as the balancing factor? Is the exchange rate endogenous?

In this regard, the paper mentioned some of the endogenous variables. 
What are the exogenous variables, are there any, and why are they exogenous?

How about the elasticities used? Where do they come from and what are they based on? If assumptions are used, was there sensitivity analysis made covering a range of assumptions? Are results sensitive to changes? I think a paragraph (or even just a footnote) on this would help.

\section{On the Interpretation and Presentation of Results}

One of the problems most people have about CGEs is that it is like a magic box. Put something in and results come out as if by magic. (This is why an explanation of the model, probably a diagram, would be useful.)

I obtained a lot of insights from the results of the models and the variables looked at. However, I think the paper could do with more elaboration of these results, especially in terms of where these results are coming from. What is the major factor contributing to the changes? Indeed, what drives the model? Providing more explanation would help demystify the CGE approach. 
